\title{
The Determinants of Life Insurance Ownership
}

\author{
Aryanti Sariartha Sianipar ${ }^{1 *}$, Arif Qaedi Hutagalung ${ }^{2}$ \\ 1,2Department of Management, Faculty of Economics and Business, Universitas Sumatera Utara, \\ Indonesia. \\ *Corresponding Author: agustina.aryantisariartha@usu.ac.id
}

\begin{abstract}
Life insurance ownership has been known as one of alternatives to mitigate the financial risk of a household. Several ethnicities in Indonesia are exposed to financial risk in terms of premature death of family members because there exists cultural traits expenditures. This paper examines the decision to own life insurance among Bataknese in Medan. The determinants of life insurance ownership observed in this study include socioeconomic and demographic factors. Data was analysed using Logit regression of 185 questionnaires after adjustments from 200 responses. The results show that the Batak ethnic in Medan owned personal life insurance because it was driven by the number of credit card limits, age, number of social gathering clan, education, residence ownership status, and bequest motives. Meanwhile, Saur matua life insurance (cultural traits) ownership is driven by factors in the order of the first child in the family, the number of brothers, life expectancy, and the condition of receiving inheritance from parents. Bataknese own life insurance affected by socioeconomic and demographic factors. This research can provide opportunities for the life insurance industry if it wants to add new features of life insurance products that are specific to ethnic groups with similar cultural heritage patterns.
\end{abstract}

Keywords $\quad$ : Bequest; Culture; Customs; Financial Plan; Life Insurance JEL Classification : G22

\section{INTRODUCTION}

Financial decisions are influenced by the lifestyle and active involvement in ethnic communities of an individual. Practicing customs in urban areas requires greater expenses than in rural areas, usually up to hundreds of millions rupiah. One of the customs that is still conserved by the Batak ethnic community is the Saur matua. The custom of Saur matua is a custom that is practiced to give respect to a late person who successfully walked all his/her children down the aisle (Katrina, 2017).

One of the financial products that can be used for this purpose is a life insurance or what is known among the Batak ethnic group as saur matua insurance. Saur matua life insurance means that the children purchase an insurance policy in which the parents are the insured parties. Meanwhile personal life insurance refers to a policy contract in which 
the person itself is the insured party. Saur matua insurance can be used as savings alternative to mitigate the aforementioned financial risks whenever the family is not financially ready to face the saur matua custom. Bataknese are often in debt to carry out these customary obligations, leaving a debt in grief (Timoria, 2019).

Based on the data from the Indonesian Life Insurance Association (AAJI) in 2015, the percentage of life insurance owners to the total population of Indonesia was $21.57 \%$, in 2016 it was $17.94 \%$; 2017 was 18.78\%, 2018 was $17.76 \%$, in 2019 it was $19.91 \%$ and 2020 was $23.82 \%$. The number of life insurance owners was decreasing during 2015 through 2018 but increasing from 2018 to 2020, Instead of the increasing trend, this value is still very small compared to countries in Asia such as Singapore, Malaysia, India and China, despite the fact that the life insurance products can provide a solution for Indonesians especially the Bataknese. If the customs of the Batak ethnic community have to be in debt frequently, most likely the culture will not be preserved by future generations. 261.874.411

Research that seeks to incorporate cultural factors has a various background to them. There are studies that include educational background and religion as cultural factors (Luciano et al., 2016; Zakaria et al., 2016). Other studies include ethnicities as part of culture (Kim \& Hanna, 2019; Gutter et al., 2020). Near to Indonesia, Akhter \& Khan (2017) observes demographic and financial development factors of life insurance ownership in ASEAN countries. However, few research that examine the determinants of life insurance ownership on ethnic specific to the dimensions of culture.

Other studies that include socioeconomic factors such as household income (Luciano et al., 2016; Moshirian et al., 2016; Akhter \& Khan, 2017; Dash, 2018; Gutter et al., 2020), the the use of financial planner (Kim \& Hanna, 2019), saving motives the desire to give inheritance (Zakaria et al., 2016) and home ownership are also determinants of life insurance ownership based on empirical findings (Kim \& Hanna, 2019; Gutter et al., 2020; Luciano et al., 2016). Previous research has focused on the demand for life insurance in the context of individuals and families that do not include cultural elements in it.

The underlying theory of demographic factors is concluded based on a study conducted by Hartley et al. (2017) which stated that insurance is purchased to maximize the lifetime utility of individuals who buy insurance, namely the main breadwinner in the family. Moshirian et al. (2016) support the hypothesis that individual's life insurance consumption is driven by the desire to leave an inheritance, known as bequest motives. The presence of children tends to increase an individual's desire to have life insurance. Other factors are gender differences, the level of education (Luciano et al., 2016), and having a child younger than 15 (Luciano et al., 2016). Meanwhile, having family members in the age ranging from 25-55 years and elderly parents has a negative effect on demand for life insurance concurring family network hypothesis which states that insurance is needed by families with a composition of young children. Other empirical facts showed that the higher the age of the insured, the higher the mortality rate and the mortality cost will also increase (Hartley et al., 2017). Additionally households with long-term savings goals - such as building houses, children's education, and emergency funds - tend to have life insurance (Zakaria et al., 2016; Kim \& Hanna, 2019). Contrary to most studies, Moshirian et al. (2016) found that life expectancy reduces the tendency of life insurance ownership. Recent studies conducted in the United States show that age, married status, education of the head of family have a positive effect on life insurance ownership (Kim \& 
Hanna, 2019). Based on the theory of life cycle, starting from getting married, having children, buying a house can determine the decision to have life insurance (Mulholland et al., 2016).

Based on this phenomenon, this research aims to examine the determinants of a life insurance ownership among the Batak ethnic group in Medan. The existing literature in developing countries which examines social and demographic factors are still limited. Thus this study strives to fulfil the research gap. The method used in this research is the Logit regression method. This study contributes to the literature in the context of cultural practice that affects an individual financial decision. Industry players can use the findings of this study to develop financial products for ethnic groups who practice similar cultures for example Toraja, and Bali. This study found that socioeconomic and demographic factors significantly affect personal life insurance and the saur matua insurance ownership.

\section{METHOD, DATA, AND ANALYSIS}

\section{Sampling}

This research involved the population of the Batak ethnic community in the city of Medan. Data obtained from the Department of Population and Civil Registry, the population of Medan City is 1,716,022 people. Based on the 2010 population census, the number of Batak tribes in Indonesia is $8,466,969$ people. The proportion of the Batak ethnic population in Medan City is estimated at $19.21 \%$, so the estimated population is 329,648 people. In selecting the sample, this study uses the snowball technique. The sample set was specific to the overall Batak ethnicity being the target. Snowball technique is a sample selection technique using a specific network from a group of individuals (Neuman, 2018). The respondents consisted of Bataknese living in Medan city that actively have source of income. Based on the sampling criteria, the number of samples in this study was 200 respondents with $7 \%$ margin of error.

\section{Data Collection}

The data was collected through a survey using a questionnaire instrument by distributing it to various networks of friends that are able to reach the Batak ethnic population in Medan City. Starting with disseminating it through social media groups consisting of ethnic Bataks and individuals are asked to pass it on to some relatives they know. Thus, from 10 networks obtained the number of respondents was 170 online and 30 offline questionnaires. So that the total respondents who responded to this study were 200 respondents.

\section{Measures}

The questionnaire instrument used is based on the adaptation of the SCF (Survey of Consumer Finance) questionnaire used in various researches in the United States (Hanna et al., 2018; Kim \& Hanna, 2019). A complete list of questions in the questionnaire can be found upon request. The dependent variables used in this study is life insurance ownership both for respondents and for parents (saur matua) as the insured parties. The detailed information of the variables in the study are summarized in Appendix 2. Independent variables consist of socioeconomic factors such as income level, loans/credit card limit, asset in the form of inheritance, the desire to give inheritance, Residence ownership status, alternative solutions during an emergency. On the other hand demographic factors comprise of age, Child birth order-, Number of brothers, Number of 
children aged $>25$, Number of children aged $<18$ years, Number of family ethnic groups that is followed, Level of education, Health status, Gender, Respondent's life expectancy.

The analysis is conducted by using logit regression analysis with two types of specifications. Mathematically, the regression model can be written in equations (1) and (2).

$$
\begin{aligned}
& L_{y 1 i}=\left(\frac{P_{i}}{1-P_{i}}\right)=\beta_{0}+\beta_{1} Z_{i}+\varepsilon_{i} \\
& L_{y 2 i}=\left(\frac{P_{i}}{1-P_{i}}\right)=\gamma_{0}+\gamma_{1} X_{i}+\varepsilon_{i}
\end{aligned}
$$

Whereas $Y_{1}$ is a dummy variable of personal life insurance ownership and $Y_{2}$ is a dummy variable of Saur matua life insurance ownership, $\mathrm{Zi}$ is a vector of explanatory variables, socioeconomic factors and demographic factors on the model of personal life insurance as the insured. $\mathrm{Xi}$ is a vector of explanatory variables, socioeconomic and demographic factors in the life insurance model with parents as the insured (saur matua life insurance).

\section{RESULTS}

\section{Descriptive Statistics}

Data analysis was carried out by referring to models (1) and (2). Before conducting logit regression, important data regarding the respondent's profile is displayed as follows. Respondents are spread across 19 districts with the majority of respondents (18.2\%) lives in Medan Selayang District. Meanwhile, based on gender, male and female respondents were balanced with a proportion of $50 \%$ each. Based on employment status, $58.8 \%$ of the respondents were workers and $37.1 \%$ were entrepreneurs. Meanwhile, based on the income level, the majority as much as $14.1 \%$ of respondents had an income level of IDR $5,000,000$ per month. Based on the level of education, the majority of respondents $(55.3 \%)$ have a Bachelor's degree. Only $12.4 \%$ of respondents have postgraduate degrees, either Masters or Doctoral degrees. In addition, $58.8 \%$ of respondents are married and $40.6 \%$ are single. Meanwhile, $70 \%$ of respondents still have parents. When it comes to protection that all family members have, only $33.6 \%$ of respondents answered that all family members have insurance. There were $66.4 \%$ of respondents stated that not all family members have insurance. This indicates the low level of awareness of the Batak community about the importance of personal financial risk management. Whereas when asked about the importance of giving an inheritance, the majority $(72.2 \%)$ of respondents answered that it is important to give an inheritance for their family. In addition, $69.8 \%$ of respondents stated that they expect to give an inheritance for their family.

\section{Personal Life Insurance Model}

The statistical results of estimation 1 is presented in table 1 . According to table 1 the socioeconomic factors such as credit card limit, home ownership, and desire to leave inheritance positively affected the personal life insurance. This means that individuals with such characteristics have higher tendencies to purchase life insurance. Meanwhile demographic factors that determine life insurance ownership age and level of education.

Table 1. Estimation Results of Personal life insurance Model

\begin{tabular}{llll}
\hline Explanatory variables & Coefficient & z-stat & Prob. \\
\hline Income level & $1.76 \mathrm{E}-08$ & 0.56 & 0.58 \\
Credit card limit & $1.38 \mathrm{E}-08^{*}$ & 1.71 & 0.08 \\
Emergency fund sources & 0.03 & 0.22 & 0.83
\end{tabular}


Age

Child to-

Number of brothers

Number of children above 25 years old

Number of children under 18 years old

Number of culture related communities involved in

Level of education

Health status

Life expectancy

Dummy homeownership

Dummy desire to leave inheritance

Constanta

Number of observations $=184$

Pseudo R2 $=0.23$

LR stat $=52.53$

Prob. LR stat $=0.00$

$\begin{array}{lll}-0.04 \text { ** } & -2.02 & 0.04 \\ 0.0029 & 0.02 & 0.98 \\ -0.14 & -0.97 & 0.33 \\ -0.15 & -0.55 & 0.58 \\ 0.17 & 0.76 & 0.45 \\ 0.29 * * * & 2.41 & 0.01 \\ 0.61 \text { ** } & 1.99 & 0.04 \\ 0.16 & 0.41 & 0.68 \\ -0.0023 & -0.79 & 0.42 \\ 1.61 \text { *** } & 3.99 & 0.00 \\ 1.00^{* *} & 2.22 & 0.03 \\ -3.91^{* *} & -2.26 & 0.02\end{array}$

Notes: Dependent variable is dummy variable personal life insurance, the value of dummy $=1$ if respondents have life insurance and 0 if otherwise. ${ }^{* * *}$ significant at $1 \%$ level; $* * 5 \%$ level; and * $10 \%$ level

Source: survey data conducted at 2020 period

\section{Saur matua Life Insurance Model}

The estimation results of model (2) is presented in table 2. According to table 2 the socioeconomic determinants of saur matua life insurance is the condition of receiving an inheritance. Additionally the demographic factors that improve the tendency to own saur matua life insurance are number of brothers and life expectancy. Meanwhile number of children above 25 years old, level of eduaction, and male lead to lower tendency to purchase life insurance.

Table 2. Estimation results of life insurance for elderly parents

\begin{tabular}{llll}
\hline Explanatory Variables & Coefficient & z-stat & Prob. \\
\hline Income level & $5.40 \mathrm{E}-08$ & 0.95 & 0.35 \\
Credit card limits & $-1.16 \mathrm{E}-08$ & -0.59 & 0.55 \\
Emergency fund sources & 0.0032 & 0.02 & 0.98 \\
Child to- & $-0.29^{*}$ & -1.66 & 0.09 \\
Number of brothers & $0.48^{* * *}$ & 2.45 & 0.01 \\
Number of children above 25 years old & $-1.41^{*}$ & -1.78 & 0.07 \\
Number of children under 18 years old & 0.009 & 0.03 & 0.98 \\
Number of culture related communities involved in & -0.16 & -0.89 & 0.37 \\
Level of education & $-0.77^{* * *}$ & -2.14 & 0.03 \\
Health status & -0.23 & -0.45 & 0.65 \\
Life expectancy & $0.003^{*}$ & 1.80 & 0.07 \\
Dummy receiving inheritance & $1.27^{*}$ & 1.92 & 0.05 \\
Dummy gender status & $-0.89^{*}$ & -1.69 & 0.09 \\
Constanta & 1.81 & 0.80 & 0.42 \\
Number of observations = 185 & & & \\
Pseudo R2 = 0.19 & & & \\
LR stat = 26.56 & & & \\
Prob. LR stat = 0.02 & & \\
\hline Notes: Dependent variable is dummy variable of life insurance for elders, the value of dummy = 1 \\
if respondents have life insurance for elders and 0 if otherwise. ${ }^{* * *}$ significant at $1 \%$ level; $*$ $5 \%$ \\
level; and * $10 \%$ level \\
Source: survey conducted in year 2020 period
\end{tabular}




\section{DISCUSSION}

\section{Personal Life Insurance Model}

Credit card limits positively related to life insurance consumption. The higher the limit given by banks on the credit card, reflects the ability to pay off loans due to higher income and the value of assets owned. Akhter \& Khan (2017) stated the higher the income reflects the awareness of an individual to life insurance products. Credit card limit reflects the existence of personal lines of credit own by an individual, thus having an issuing debt requires a protection of the debtor in the form of life insurance. This might be a feature required by the lenders either as an obligatory or as a collateral (Nam \& Hanna, 2018; Kim \& Hanna, 2019).

Meanwhile, respondents who have their own house, in fact 5 times more likely to have life insurance than respondents who do not own a house. Respondents who wish to give an inheritance are 3 times more likely to purchase personal life insurance with themselves as the insured than those who do not wish to give an inheritance supporting studies by (Zakaria et al., 2018; Kim \& Hanna, 2019; Gutter et al., 2020). Home ownership represents the number of assets owned, a long-term orientation in financial decisions, and capabilities of buying and planning its finances. Another finding is that the variable related to the desire to give an inheritance that positively affect life insurance ownership are in line with the theory of bequest motives (Tan, 2018).

The higher the age, the lower the possibility of the respondent having life insurance. This result contraries to the research conducted by Meko et al. (2019) that longer life expectancies indicate that higher savings. Bataknese who have higher life expectancies tend to have higher level of wealth and lower probability of the income earner's premature death, thus decreases the willingness to own life insurance Moshirian et al. (2016).

The higher the education, the higher the desire to have life insurance. As indicated in table 1 respondents with a better education are 2 times more likely to protect their families from financial risks. Individuals with better education tend to have a strong desire to protect their family and a desire to give an inheritance (Luciano et al., 2016). Thus this argument supports the theory of bequest motives. Moreover, the higher the education the higher the capacity they have to diversify their savings (Outreville, 2018). Another study in India shows that households that have life insurance are those with higher education (Moshirian et al., 2016 Dash, 2018). Sin (2018) studied Malays, Chinese, and Indians in Malaysia found that tertiary-educated people desire life insurance due to better understanding about life insurance benefit and risk management compared to the less-educated ones.

On the cultural side, the variables related to the number of social gathering/communities that bring the Batak ethnic community in Medan to the Batak culture positively affect personal life insurance ownership. There is 1.3 times the likelihood of people who are active in clan associations buying life insurance when compared to those who involve in a few ethnic groups. These results support the life cycle hypothesis which states that life insurance ownership is increasingly necessary in the household life phase. When individuals start a household and have children, they are expected to be active in customary and cultural associations according to their clan and spouse's clan. In anticipation of this risk, life insurance can be considered for purchase. Research in Malaysia provides empirical facts that religion is also a determinant of life 
insurance ownership (Zakaria et al., 2016). Additionally, Outreville (2018) found that religion affects life insurance consumption. The studies concluded that among Christian, Muslim, and Buddhist, Muslim countries tend to have lower life insurance ownership. Activities in clan associations are generally related to religious rituals in the Batak community. Another explanation is provided by Akhter \& Khan (2017) who found that urbanisation increased the consumption of life insurance in the ASEAN region. This was due to the level of urbanisation lead to the development of insurance sector. Bataknese's hometown is known from a village near Toba Lake, around hundreds of kilometers from capital city province. The urbanisation causes the Bataknese to gather with their communities to build a strong family networks. They practices cultural traits frequently and thus they tend to demand life insurance as an alternatives of mitigating household's financial risks.

\section{Saur matua Life Insurance Model}

Hartley et al. (2017) provides data that the top three reasons Americans own life insurance are to cover funeral expenses, to replace income lost, and to cover mortgage debt. The regression model (2) shows the determinants of insurance ownership for parents as the insured or often referred to as "saur matua" life insurance is condition of receiving inheritance. This is reasonable because the Batak ethnic parents leave an inheritance for their children to be used and looked after, such as a house, rice fields, or land. So that children are more oriented to protect the parents' inheritance by buying life protection. The sum insured obtained from saur matua life insurance is in the form of cash when the parent dies when the children's financial condition is inadequate (Junita, 2018; Hartley et al., 2018).

The demographic factor that determines the ownership of Saur matua life insurance according to table 2 is the order of the children in the family. This means that the firstborn is the child who most definitely purchase Saur matua life insurance. This is in accordance with the traditional Batak cultural structure which makes the first child as a substitute for their parents when they die, including in financial matters. Expenses that must be planned include customary costs and transportation to the parents' house (Hasugian, 2017).

The more the number of brothers, the tendency to buy saur matua life insurance is 1.6 times higher than those with fewer brothers. The boy in the Batak ethnic custom is one of the successors of the clan generation. So that the greater number of brothers they have, the more it will require high costs for the funeral of the parents who died. Meanwhile, when the Batak ethnic community has more children over 25 years of age, the less they have saur matua life insurance. This is due to the increasing number of children who are economically independent, the older they are, so they don't need life insurance for their parents. This is because the family's financial condition is already in good stages. Kim \& Hanna (2019) lower life insurance consumption was due to no surviving dependants that need financial supports.

Respondents with high education tend to be 2 times lower in terms of saur matua life insurance than those with lower education. This result is consistent with the argument that the better the education the ability to manage their own financial risks is also better (Kim \& Hanna, 2019). Akhter \& Khan (2017) argued in ASEAN countries education negatively affect sharia insurance ownership, this was due to low awareness of the product benefits and features. Saur matua life insurance is still unfamiliar among 
Bataknese. This finding suggests the practitioners to improve the awareness of life insurance benefits to saur matua to Bataknese communities. The next finding is that the higher the life expectancy, the higher the tendency to have Saur matua life insurance. The higher the life expectancy the more they think for a long-term orientation. This supports the theory of bequest motives (Nam \& Hanna, 2018). Another findings that women tend to need financial protection when their parents die. Female children inherit lower portion of their parent's assets, but on the other hand they have to support the traditional funeral expenses related to cultural practices. Thus, female Bataknese tends to need saur matua life insurance. Another reason that explains this result is that women are known to have more risk-averse characteristics than men. So that women tend to need financial planning that can protect themselves from this financial burden (Luciano et al., 2016).

\section{CONCLUSION, LIMITATIONS, AND SUGGESTIONS}

\section{Conclusion}

Insurance industries play an important role to the development of a country's financial system. Thus, the advance of this institutions are important, this includes how this industry can attract potential customers by knowing the determinants of their financial decision to own life insurance.

Based on the logistic regression, it can be concluded that the determinants of personal life insurance ownership are credit card limit, age, number of social gathering clan, education, residence ownership status, and the desire to leave a legacy. Batak ethnic community tends to follow the theory of bequest motives, and lifetime utility theory. These results also support the life cycle hypothesis which states that when the Batak ethnic community starts to marry, they will become more involved in customs and thus need life insurance.

The demographic factors that determine ownership of saur matua life insurance are, the number of brothers, status of firstborn in the family, and life expectancy. This is in line with the bequest motives hypothesis that inheritance from parents needs to be maintained. Meanwhile, factors such as the number of children over 25 years old, education, and male gender have a smaller tendency to have Saur matua life insurance.

\section{Limitation and suggestions}

Bataknese is among the ethnicities who have various ceremonies from the stage of life such as birth to death. In the context of cultural traits, the household's financial conditions might be at risk if the society is not aware of financial products such as life insurance. According to this study, Bataknese who have personal lines of credits, involve in many culture related communities, own a house are the ones who need life insurance to prevent the family members having a great burden from premature death of the breadwinner. Bataknese who concern about giving an appreciation to his/her parents as part of preserving the customs might consider an expenditure in life insurance when it has a large number of brothers, higher life expectancy, and receive inheritance.

This research also contributes to the financial industry, especially life insurance, in terms of market potential for the Batak ethnic community. The marketing campaign for this ethnic group is still open. In addition, the industry can also formulate specific product features according to the needs of the Batak community such as saur matua life insurance with these specific characteristics: female customer, firstborn in the family, low eduacted, and have children above 25 years old. Insurance companies might consider to 
give lower premium, more incentives and/or further explanation about the benefits of insurance to such potential customers. This study suggests that insurance companies campaign to older or oldest Bataknese about the benefits of life insurance so that they consider this product as an important part of their financial plans.

In this research, the samples are limited to Bataknese as one of ethnicities that practice cultural but related to financial issues of the family members. Meanwhile, there exists other ethnicities which have the same cultural traits. Future research is expected to have a wider sample size or involve several ethnic groups such as Toraja, Chinese, and Balinese This study also performed only two dummy variables due to the using of logit model. Further research might also prefer non logistic regression to find the determinants of life insurance ownership in terms of premium paid and the number of sum assured.

\section{ACKNOWLEDGMENT}

This research is funded by Universitas Sumatera Utara (USU) according to a contract named "Surat Perjanjian Penelitian Talenta Universitas Sumatera Utara Skema Penelitian Dosen Muda/Pemula Tahun Anggaran 2020" Number: 243/UN5.2.3.1/PPM/SPPTALENTA USU/2020.

\section{REFERENCES}

Akhter, W., \& Khan, S. U. (2017). Determinants of Takāful and conventional insurance demand: A regional analysis, Cogent Economics and Finance, 5, 129-150. http://dx.doi.org/10.1080/23322039.2017.1291150.

Dash, G. (2018). Determinants of Life Insurance Demand: Evidences From India. Asia Pacific Journal of Advanced Business and Social Studies, 4(2), 86-99.

Gutter, M. S., Hatcher, C. B., \& Hatcher, C. B. (2020). Racial Differences in the Demand for Life Insurance. The Journal of Risk and Insurance, 75(3), 677-689. https://doi.org/10.1111/j.1539-6975.2008.00279.x.

Hanna, S. D., Kim, K.T., Lindamood, S. (2018). Behind the Numbers: Understanding the Survey of Consumer Finances. Journal of Financial Counseling and Planning, 29(2), 410-419. http://dx.doi.org/10.1891/1052-3073.29.2.410.

Hartley, D., Paulson, A., \& Powers, K. (2017). What Explains the Decline in Life Insurance Ownership?. Economic Perspectives, (8), 1-20.

Hasugian, R. M. (2017). Upacara Kematian Saur matua Batak Toba: Analisis Tradisi Lisan. LINGUA, 14(2), 225-242.

Junita, E. (2016). Ceremony of Death in The Indigenous Community Saur Matua Batak Toba (Case Study on Family Readiness) in Village Purbatua Purbatua Sub District North Tapanuli. JOM FISIP, 3(1), 1-15.

Katrina, E. (2017). Saur matua Etnik Batak Toba: Kajian Wacana Kritis. Skripsi. Program Studi Sastra Batak Fakultas Ilmu Budaya Universitas Sumatera Utara.

Kim, K. T., \& Hanna, S. D. (2019). The decrease in life insurance ownership : Implications for financial planning. Financial Services Review, (July). 
Luciano, E., Outreville, J. F., \& Rossi, M. (2016). Life Insurance Ownership by Italian Households: A Gender-Based Differences Analysis. The Geneva Papers on Risk and Insurance Issues and Practice, (December 2012). https://doi.org/10.1057/gpp.2016.7.

Meko, M., Lemie, A., \& Abel, W. (2019). Determinant of life insurance demand in Ethiopia. Journal of Economics, Business \& Accountancy Ventura, 21(3), 293-302.

Moshirian, F., Nguyen, P., \& Wee, T. (2016). The Demand Countries for Life Insurance in OECD. The Journal of Risk and Insurance, 74(3), 637-652.

Mulholland, B., Finke, M., \& Huston, S. (2016). Understanding The Shift in Demand For Cash Value Life Insurance. Risk Management and Insurance Review, 19(1), 7-36.

Nam, Y., \& Hanna, S.D. (2018). The Effects of Risk Aversion on Life Insurance Ownership of Single-Parent Households. Applied Economics Letters. https://doi.org/10.1080/13504851.2018.1546044.

Neuman, W. L. (2018). Metodologi Penelitian Sosial . Published by Indeks.

Outreville, J. F. (2018). Culture and Life Insurance, is It an Issue?. Journal of Insurance Issues, 41(2), 168-192. https://www.jstor.org/stable/26505753.

Pitoyo, A. J., \& Triwahyudi, H. (2018). Dinamika Perkembangan Etnis di Indonesia dalam Konteks Persatuan Negara. Populasi, 25(1), 64. https://doi.org/10.22146/jp.32416.

Sin, T.S. (2018). The determinants of life insurance ownership : the mediating effect of risk perception. Dissertation. Othman Yeop Abdullah Graduate School of Business, Universiti Utara Malaysia. Kedah.

Timoria, L. (2019). Kesiapan Keluarga Dalam Upacara Adat Kematian Saurmatua Pada Suku Batak Toba Desa Muliorejo Kabupaten Deli Serdang Kota Medan Sumatera Utara. Skripsi. Program Studi Pendidikan Sejarah Fakultas Keguruan dan Ilmu Pendidikan Universitas Lampung.

Zakaria, Z., Marina, N., Fakrul, N., \& Nik, H. (2016). The Intention to Purchase Life Insurance: A Case Study of Staff in Public Universities. Procedia Economics and Finance, 37(16), 358-365. https://doi.org/10.1016/S2212-5671(16)30137-X. 
Appendix 1. Operationalization of Research Variables

\begin{tabular}{|c|c|c|}
\hline Variable & Definition & Scale \\
\hline \multicolumn{3}{|l|}{ Dependent Variable } \\
\hline $\begin{array}{l}\text { Dummy of life insurance ownership for } \\
\text { yourself as the insured (Y1) }\end{array}$ & $\begin{array}{l}\text { Dummy variable }=1 \text { have life insurance } \\
\text { Dummy variable }=0 \text { if otherwise }\end{array}$ & Nominal \\
\hline $\begin{array}{l}\text { Dummy of life insurance ownership for } \\
\text { parents as the insured/ saur matua (Y2) }\end{array}$ & $\begin{array}{l}\text { Dummy variable }=1 \text { if they have } \\
\text { Dummy variable }=0 \text { if otherwise }\end{array}$ & Nominal \\
\hline \multicolumn{3}{|l|}{ Independent Variable } \\
\hline Income level & Total income of respondents & Ratio \\
\hline Loans/credit cards & Credit card limit given & Ratio \\
\hline Asset in the form of inheritance & $\begin{array}{l}D=1 \text { if you receive an inheritance; } D= \\
0 \text { if otherwise }\end{array}$ & Nominal \\
\hline The desire to give inheritance & $\begin{array}{l}\text { Dummy variable }=1 \text { if yes; dummy } \\
\text { variable }=0 \text { if otherwise }\end{array}$ & Nominal \\
\hline Residence ownership status & $\begin{array}{l}\text { Dummy }=1 \text { if owned; dummy }=0 \text { if } \\
\text { otherwise }\end{array}$ & Nominal \\
\hline $\begin{array}{l}\text { Alternative solutions during an } \\
\text { emergency }\end{array}$ & $\begin{array}{l}\text { Saving }=1 ; \text { Delaying payment }=2 ; \\
\text { Issuing assets }=3 ; \text { Borrowing }=4\end{array}$ & Ordinal \\
\hline \multicolumn{3}{|l|}{ Demographic Factors : } \\
\hline Age & Respondent age level & Ratio \\
\hline Child birth order- & Birth order in the family & Ratio \\
\hline Number of brothers & The number of brothers owned & Ratio \\
\hline Number of children aged $>25$ & $\begin{array}{l}\text { The number of dependent children } \\
\text { aged }>25 \text { years old }\end{array}$ & Ratio \\
\hline Number of children aged $<18$ years & $\begin{array}{l}\text { The number of dependent children } \\
\text { aged }<18 \text { years old }\end{array}$ & Ratio \\
\hline $\begin{array}{l}\text { Number of family ethnic groups that is } \\
\text { followed }\end{array}$ & $\begin{array}{l}\text { The number of cultural communities } \\
\text { that are followed }\end{array}$ & Ratio \\
\hline Level of education & $\begin{array}{l}\text { Education category taken } 1=\text { Primary } \\
\text { School; } 2=\text { Secondary School; } 3=\text { High } \\
\text { School; } 4=\text { Bachelor; } 5=\text { Master; } 6= \\
\text { Doctoral }\end{array}$ & Ordinal \\
\hline Health status & Perceptions of health conditions & Interval \\
\hline Gender & $\begin{array}{l}\text { Dummy }=1 \text { if male; dummy }=0 \\
\text { otherwise }\end{array}$ & Nominal \\
\hline Respondent's life expectancy & Life expectancy & Ratio \\
\hline
\end{tabular}

Notes: -

Source: previous literatur 